\title{
Green Synthesis of Copper Oxide Nanoparticles Using Aerva javanica Leaf Extract and Their Characterization and Investigation of In Vitro Antimicrobial Potential and Cytotoxic Activities
}

\author{
Fozia Amin, ${ }^{1}$ Fozia, ${ }^{2}$ Baharullah Khattak, ${ }^{1}$ Amal Alotaibi $\left(\mathbb{D},{ }^{3}\right.$ Muhammad Qasim, ${ }^{1}$ \\ Ijaz Ahmad, ${ }^{4}$ Riaz Ullah $\mathbb{D}^{5},{ }^{5}$ Mohammed Bourhia ${ }^{D},{ }^{6}$ Anadil Gul, ${ }^{7}$ Saira Zahoor, ${ }^{8}$ \\ and Rizwan Ahmad (D) \\ ${ }^{1}$ Department of Microbiology, Kohat University of Science \& Technology, Kohat, Pakistan \\ ${ }^{2}$ Biochemistry Department, KMU Institute of Medical Sciences, Kohat, Pakistan \\ ${ }^{3}$ Basic Science Department, College of Medicine, Princess Nourah Bint Abdulrahman University, Riyadh 11564, Saudi Arabia \\ ${ }^{4}$ Department of Chemistry, Kohat University of Science \& Technology, Kohat, Pakistan \\ ${ }^{5}$ Department of Pharmacognosy (MAPPRC), College of Pharmacy, King Saud University, Riyadh, Saudi Arabia \\ ${ }^{6}$ Laboratory of Chemistry-Biochemistry, Environment, Nutrition, and Health, Faculty of Medicine and Pharmacy, \\ Hassan II University, B.P. 5696, Casablanca, Morocco \\ ${ }^{7}$ Beijing Key Laboratory for Green Catalysis and Separation, Department of Chemistry and Chemical Engineering, \\ Beijing University of Technology, Beijing 100124, China \\ ${ }^{8}$ Department of Pharmaceutics, College of Clinical Pharmacy, Imam Abdulrehman Bin Faisal University, P.O. Box 1982, \\ Dammam 31441, Saudi Arabia \\ ${ }^{9}$ Department of Natural Products and Alternative Medicines, College of Clinical Pharmacy, \\ Imam Abdulrahman Bin Faisal University, Dammam, Saudi Arabia
}

Correspondence should be addressed to Amal Alotaibi; amaalotaibi@pnu.edu.sa and Riaz Ullah; rullah@ksu.edu.sa

Received 23 February 2021; Revised 26 May 2021; Accepted 4 June 2021; Published 19 June 2021

Academic Editor: Weicheng $\mathrm{Hu}$

Copyright (c) 2021 Fozia Amin et al. This is an open access article distributed under the Creative Commons Attribution License, which permits unrestricted use, distribution, and reproduction in any medium, provided the original work is properly cited.

The development of green technology is creating great interest for researchers towards low-cost and environmentally friendly methods for the synthesis of nanoparticles. Copper oxide nanoparticles (CuO-NPs) attracted many researchers due to their electric, catalytic, optical, textile, photonic, monofluid, and pharmacological activities that depend on the shape and size of the nanoparticles. This investigation aims copper oxide nanoparticles synthesis using Aerva javanica plant leaf extract. Characterization of copper oxide nanoparticles synthesized by green route was performed by three different techniques: X-Ray Diffraction (XRD), Fourier Transform Infrared (FTIR) Spectroscopy, and Scanning Electron Microscopy (SEM). X-ray diffraction (XRD) reveals the crystalline morphology of CuO-NPs and the average crystal size obtained is $15 \mathrm{~nm}$. SEM images showed the spherical nature of the particles and size is lying in the $15-23 \mathrm{~nm}$ range. FTIR analysis confirms the functional groups of active components present in the extract which are responsible for reducing and capping agents for the synthesis of CuO-NPs. The synthesized $\mathrm{CuO}-\mathrm{NPs}$ were studied for their antimicrobial potential against different bacterial as well as fungal pathogens. The results indicated that $\mathrm{CuO}-\mathrm{NPs}$ show maximum antimicrobial activities against all the selected bacterial and fungal pathogens. Antimicrobial activities of copper oxide nanoparticles were compared with standard drugs Norfloxacin and amphotericin B antibiotics. Minimum inhibitory concentration (MIC) and minimum bactericidal concentration (MBC) of copper oxide nanoparticles were $128 \mu \mathrm{g} / \mathrm{mL}$ against all selected bacterial pathogens. MIC of fungus and minimum fungicidal concentration (MFC) of CuO-NPs were $160 \mu \mathrm{g} / \mathrm{mL}$. Thus, CuO-NPs can be utilized as a broad-spectrum antimicrobial agent. The cytotoxic activity of the synthesized $\mathrm{CuO}-\mathrm{NPs}$ suggested that toxicity was negligible at concentrations below $60 \mu \mathrm{g} / \mathrm{mL}$. 


\section{Introduction}

Nanotechnology is one of the essential areas of research in modern sciences. The field of nanotechnology is expanding very rapidly, creating an incredible impact on human life including pharmaceutical, food, health, chemical industry, electronics, energy science, cosmetics, space industries, and environmental sciences [1]. The interest in nanotechnologyderived products is rapidly increasing. Nanotechnology that is the inventive innovation in the present situation can enhance human well-being and also create a great effect on the improvement of human health [2].

The synthesis process of nanomaterials and the investigation of their applications and properties are one of the inspiring parts of the advanced scientific research. Recently, science and technology have made many advances; particularly, nanotechnology helps improve an advanced concept of synthesizing nanosized material of desired size and shape [3]. Different physical and chemical methods are used for the synthesis of metal oxide nanoparticles; however, the conventionally used methods such as sol-gel, chemical reduction, and hydrothermal are costly methods and nonecofriendly by producing toxic chemicals as end products [4]. Thus, ecofriendly methods for the synthesis of metal oxide nanoparticles attracted the attention such as the use of plant extract, microorganisms, and algae. But among biological methods, the use of plant extract was more favored due to its easy handling, easy availability, cost-effectiveness, and compatibility with the biomedical application such as drug delivery, cancer treatment, antibacterial and antifungal agent, and insecticide treatment [4].

In the phytosynthesis approach, the synthesis of nanoparticles is carried out by using plant extracts as a capping and reducing agent. Among metal oxide NPs like $\mathrm{Ni}, \mathrm{Cu}, \mathrm{Zn}, \mathrm{Au}$, and $\mathrm{Fe}$, the synthesis of $\mathrm{CuO}-\mathrm{NPs}$ is considered promising NPs; they are cheaper than other Nobel metals. Metal oxide NPs like $\mathrm{CuO}$ have been pulled into consideration generally due to their biocidal properties and they might be utilized as an effective part of numerous biomedical applications such as biomedical imaging, drug delivery, cellular delivery, and disease treatment [5]. CuO-NPs are utilized as heterogeneous catalysts, used in drug delivery, antioxidants, anticancer, and treatment agents in the pharmaceutical field [6]. CuO-NPs are exploited in the healing of wounds and socks to give them biocidal properties. Furthermore, $\mathrm{CuO}-\mathrm{NPs}$ create a great potential in industrial use including gas sensors, catalytic processes, and solar cells high-temperature superconductors [6]. Copper nanoparticles can oxidize easily to form copper oxide [7]. Copper oxide NPs are highly valuable antimicrobial particles because they possess very unusual crystal structures and possess high surface areas [8]. These nanoparticles are robust and very stable, and the shelf life of Copper oxide NPs is too long compared to other organic antimicrobial agents [8]. Various synthesis methods are used for $\mathrm{CuO}$ synthesis such as chemical precipitation, electrochemical reduction, microwave irradiation, and thermal decomposition plants, which attracted many researchers in green route for the synthesis of copper, but in the chemical method, the use of toxic chemicals limited its applications. Thus, the synthesis of $\mathrm{CuO}-\mathrm{NPs}$ using the biological method gains more attention due to its easy availability, easy handling, elimination of cell culture, and being ecofriendly [7]. Thus, using plant extract for the synthesis of oxide NPs is already reported, Carica papaya [9], Aloe barbadensis [10], Malva sylvestris [11], and Gloriosa superba [12].

Nanoparticles (NPs) are progressively utilized to target bacteria and fungi as a contrasting option to antibiotics. Nanotechnology might be worthwhile in the treatment of microbial infections. Bacterial infections are the endless cause of chronic infections and mortality. Antibiotics played a very effective role in the treatment strategy for different infections, which are caused by bacteria due to their cost-effectiveness and intense results. Several investigations have given direct confirmation that the broad spectrum utilization of antibiotics creates generation of the strains of multidrug-resistant bacteria and fungi. The super bacteria and fungi are types of microbial strains that show resistance against all the antibiotics, which have been developed recently because of the abuse of antibiotics [13]. The main groups of antibiotics are presently being used active in three different modes on the synthesis of cell wall, translational and on the DNA replication mechanisms Bacteria are resistant to all these modes of action. The mechanisms of resistance include enzyme expression that modifies or degrade many antibiotics, such as aminoglycosides and $\beta$-lactamases modification of cell components, including the vancomycin cell wall resistance bacteria and ribosome that are present in bacteria resistant to tetracyclines and efflux pumps expression, which provide resistance against many antibiotics. Many resistance mechanisms produced against antibiotics are unessential for NPs because the action of NPs is directly in contact with the cell wall of bacteria and not penetrating the cell; this gives the expectations that NPs would be very less prone to promoting bacterial resistance when contrasted to antibiotics. Thus, consideration has been dropped on new and effective NPbased materials with antibacterial activity [6].

In the present study, copper oxide nanoparticles were synthesized through a green route using Aerva javanica plant leaf extract. The plant Aerva javanica (Amaranthaceae) is a perpetual herb and a tall and woolly under shrub found plentifully in all rainy seasons and generally conveyed in different areas all over the world. This plant is local to Africa and also exists in a portion of the Asian nations [14]. In conventional herb, it is utilized for many purposes such as for diabetic patients and also utilized to clear swelling [15]. The powdered form of this plant is used for ulcer. The plant seeds are utilized to alleviate migraine and furthermore stiffness. A. javanica is examined to possess hypoglycemic, antioxidant, antimalarial, antihlmintic, analgesic, antivenin activities and medicinal applications against kidney troubles and rheumatism [16]. A. javanica also showed different activities including antiviral [17], antiplasmodial [18], and antidiabetic [19]. Some important phytochemicals such as steroids [20], triterpenoids [21], sugars [22], and flavonoids [23] have been 
accounted for Aerva javanica earlier. The phytochemical flavonoids mainly act as a reducing and stabilizing agent and are responsible for the synthesis of the CuO-NPs.

To the best of our knowledge, no report is accessible on the green synthesis of $\mathrm{CuO}-\mathrm{NPs}$ using leaf extract of Aerva javanica. The present study explores the green synthesis of $\mathrm{CuO}-\mathrm{NPs}$, their characterization, and investigation of in vitro antimicrobial and cytotoxic activities.

\section{Materials and Methods}

2.1. Materials. The copper (II) sulfate pentahydrate $\left(\mathrm{CuSO}_{4} \cdot 5 \mathrm{H}_{2} \mathrm{O}\right)$ percent purity is $98 \%$. Pure bacterial and fungal pathogen cultures were obtained from the Microbiology Department, KUST. Dimethyl sulfoxide (DMSO), Mueller-Hinton agar (MHA), potato dextrose agar (PDA), neuroblastoma (Neuro2A) cells, streptomycin, penicillin, Dulbecco media (1 g/ 1 glucose; $2 \mathrm{mM}$ glutamine), and 3-(4,5-dimethylthiazol-2-yl)2,5 diphenyltetrazolium bromide (MTT) were used.

2.2. Plant Collection and Extraction. The leaves of A. Javanica were obtained from hilly areas of District Karak, Pakistan. The fresh leaves of A. Javanica were then washed in tap water, cut into tiny small pieces, and dried at room temperature under the shade. About $250 \mathrm{~g}$ of chopped leaves was weighed and powdered mechanically using grinder and dipped in methanol separately for 14 days. The filtrates were subjected to extraction under low pressure at $40^{\circ} \mathrm{C}$ by using a rotary flash evaporator to give the final extract $(15.50 \mathrm{~g})$. A very small amount of the extract $(0.1 \mathrm{~g} / \mathrm{ml})$ is used for synthesizing $\mathrm{CuO}-\mathrm{NPs}$ [24].

2.3. Green Synthesis of Copper Oxide Nanoparticles. For the synthesis of $\mathrm{CuO}-\mathrm{NPs}$, the optimized concentration ratio of $50 \mathrm{ml}$ of aqueous $4 \mathrm{mM}$ copper chloride dihydrate $\left(\mathrm{CuCl}_{2} \cdot 2 \mathrm{H}_{2} \mathrm{O}\right)$ and $2 \mathrm{ml}$ aqueous leaf extract of $A$. javanica was treated and magnetically stirred; slowly and gradually, the mixture changes its light blue color to light green color. The mixture is then subjected to heating at $80^{\circ} \mathrm{C}$ for 2 hours. According to reported literature, the particle size of nanoparticles increases slightly up to the range of $70-80^{\circ} \mathrm{C}$ and the increase becomes sharped within the range of $80-90^{\circ} \mathrm{C}$; thus, we selected $80^{\circ} \mathrm{C}$ for $2 \mathrm{~h}$ on the basis of all these reasons. After drop-by-drop addition of $1 \mathrm{M}$ sodium hydroxide to the mixture, sodium hydroxide comes in contact with the copper ions; the mixture changes the color spontaneously from green to brownish-black precipitate and gives an indication of the formation of CuO-NPs [24]. The brown precipitate solution was then centrifuged for 15 minutes at $10,000 \mathrm{rpm}$ and repeatedly washed with deionized water after that followed by washing with ethanol to remove all the impurities that are present; then a brownish-black powder was obtained after overnight drying at $60^{\circ} \mathrm{C}$ in a furnace [25].

2.4. Characterization of Copper Oxide Nanoparticles. The synthesized $\mathrm{CuO}-\mathrm{NPs}$ were characterized by using spectralanalytical techniques including X-ray Diffraction (XRD)
Analysis, Scanning Electron Microscopy (SEM) Analysis, and Fourier Transform Infrared (FTIR) Microscopy.

2.4.1. X-Ray Diffraction Analysis (XRD). The synthesis of $\mathrm{CuO}-\mathrm{NPs}$ was confirmed by X-ray diffractometer using $\mathrm{CuKa}$ as a radiation source with a wavelength of $1.5406 \AA$. The XRD technique was performed in the $2 \theta$ range of $30-70$, to examine the crystalline structure and phase of copper oxide.

2.4.2. Scanning Electron Microscopy Analysis (SEM) Analysis. The structural morphology, shape, and size of the synthesized copper oxide NPs was were analyzed by using scanning electron microscopy (JEOL Japan).

2.4.3. Fourier Transform Infra Red Microscopy (FTIR). This technique is used to find out the functional groups present in synthesized copper oxide NPs, because each chemical bond has an energy absorption band used to examine the structural and bond information of complex to study bonding type and their strength. The FTIR spectra of synthesized samples were obtained by using the $\mathrm{KBr}$ pellet method, in the range of $4000-400 \mathrm{~cm}^{-1}$ with a resolution of $4 \mathrm{~cm}^{-1}$.

2.4.4. UV-Visible Spectroscopy. The initial synthesis of nanoparticles was confirmed by a UV-visible spectrophotometer (Shimadzu UV-2600) in the range of $200-800 \mathrm{~nm}$.

2.5. Biological Assays. Stock solutions of CuO-NPs were made in DMSO $1 \mathrm{mg} / \mathrm{mL}$ concentration and then diluted to $50 \mu \mathrm{g} / \mathrm{mL}, 100 \mu \mathrm{g} / \mathrm{mL}$, and $200 \mu \mathrm{g} / \mathrm{mL}$, respectively. Pure bacterial and fungal pathogen cultures were obtained from the Microbiology Department, KUST, and identified by culture and microscopic analysis. Before the susceptibility testing, the bacteria were first cultured on the surface of nutrient agar. Their fresh culture obtained was subcultured on Muller Hinton agar (MHA) for bacterial susceptibility testing of Copper oxide NPs.

2.5.1. Antibacterial Activity. Fresh cultures of bacteria (adjusted to the standard $0.5 \mathrm{McF}$ arland turbidity) were swabbed on the surface of MHA media using cotton swabs after solidification of media. In the agar well diffusion method, in all Petri plates, three wells were formed with the help of sterile cork borer ( $6 \mathrm{~mm}$ wells). For the antibacterial activity test at a concentration of $50 \mu \mathrm{g} / \mathrm{mL}$, three sets of Petri plates were prepared for all bacteria. All the plate wells have copper oxide nanoparticles, A. javanica extract, and dimethyl sulfoxide (DMSO) as a negative control. In the first set of plates, the well concentration of the sample was $50 \mu \mathrm{g} /$ $\mathrm{ml}$, in the second set of plates, wells contain a concentration of sample $100 \mu \mathrm{g} / \mathrm{ml}$, and the third set of plates contain a concentration of $200 \mu \mathrm{g} / \mathrm{ml}$. Each plate well contained copper oxide nanoparticle, A. javanica extract, and DMSO as a negative control. The quantity of sample used was $50 \mu \mathrm{l}$ approximately. All the Petri plates were then placed in 
incubation for 24 hours at $37^{\circ} \mathrm{C}$. Then zones of inhibition were measured [26].

2.5.2. Antifungal Activity. The fungus was cultured on the surface of potato dextrose agar (PDA) Petri plates before being incubated at $37^{\circ} \mathrm{C}$ for 2-3 days. The fungus was spread on the surface of Muller Hinton agar (MHA) media using cotton swabs when solidified. For the agar well diffusion method, with the help of sterile cork borer, three wells were formed in all Petri plates. For negative control, DMSO was used. Then all the plates were subjected to incubation at $27^{\circ} \mathrm{C}$ for 48-72 hours; then inhibition zones were measured.

2.5.3. Minimum Inhibitory Concentrations (MICs). MIC is the lowest concentration of antimicrobial agents which inhibit microbial growth. The antimicrobial activity of copper oxide NPs was calculated using the standard broth dilution method (CLSI M07-A8). BHI broth was used for MIC calculation by twofold serial dilutions of CuO-NPs. Different concentrations were used starting from $8 \mu \mathrm{g} / \mathrm{mL}$ to $156 \mu \mathrm{g} / \mathrm{mL}$ with an adjusted bacterial concentration of 0.10 at $625 \mathrm{~nm}(1 \times 108 \mathrm{CFU} / \mathrm{ml}, 0.5 \mathrm{McF}$ arland's standard $)$. Tested bacterial concentration in BHI broth was used as positive control and the only broth was used as a negative control. The incubation time and temperature were $24 \mathrm{~h}$ and $37^{\circ} \mathrm{C}$. The MIC was calculated visually by the turbidity of the tubes before and after the incubation, and it was performed in six sets to calculate its value for the selected bacteria. After the MIC measurement of the CuO-NPs, $50 \mu \mathrm{l}$ sample from all the tubes was swabbed on plates; the plates that showed no visible bacterial growth were cultured in BHI agar plates and were incubated for 24 hours at $37^{\circ} \mathrm{C}[27]$.

2.5.4. Minimum Bactericidal Concentrations (MBCs). $\mathrm{MBC}$ is the lowest concentration of antimicrobial agent that kills all the bacteria. MBC was performed with same MIC steps. Those plates that have no bacterial growth were considered to be MBC.

\subsection{Cytotoxic Activity of CuO-NPs}

2.6.1. Cell Culture. Neuroblastoma (Neuro2A) cells were incubated with 10 percent FBS, $100 \mu \mathrm{g} / \mathrm{mL}$ streptomycin, and $100 \mathrm{U} / \mathrm{ml}$ penicillin at a temperature of $37^{\circ} \mathrm{C}$ and 5 percent humidity in the modified Dulbecco media ( $1 \mathrm{~g} / \mathrm{l}$ glucose; $2 \mathrm{mM}$ glutamine) [28].

2.6.2. Cytotoxicity Evaluation. Using 3-(4,5-dimethylthiazol-2-yl)-2,5 diphenyltetrazolium bromide (MTT), the cytotoxic activity of prepared $\mathrm{CuO}-\mathrm{NPs}$ was calculated. In short, $200 \mu \mathrm{L}$ of cell suspension was applied to a $96-$ well (1 to 104 cell/well) tissue culture plate and incubated at $37^{\circ} \mathrm{C}$ for 24 hours. Then, $50 \mu \mathrm{L}(0-600 \mu \mathrm{g} / \mathrm{ml})$ of the synthesized nanoparticles was poured into each well, while the plate was incubated for 24 hours. In this project, as the control, we identified the cell suspension that held the culture medium.
Then $20 \mu$ l of the MTT-containing PBS buffer $(5 \mathrm{mg} / \mathrm{ml})$ was appended to each well, while the plate was incubated at $37^{\circ} \mathrm{C}$ for 4 hours. At the end of each well, $100 \mu \mathrm{l}$ of DMSO was applied and their optical absorbance was measured at $570 \mathrm{~nm}$, which was accomplished by applying a microplate reader. Cell viability relative to control was expressed as a percentage [28].

2.7. Statistical Analysis. All the experiments were performed in three repeats. All the data were calculated as a mean\pm standard error, using GraphPad PRISM 6 software.

\section{Results and Discussion}

3.1. X-Ray Diffraction Analysis. The copper oxide nanoparticles synthesized by using the green method from plant A. javanica are confirmed by the peaks observed (Figure 1). The peak position is at $2 \theta$ of $32.41,35.61,38.81,48.91,53.32$, $58.22,60.61$, and 63.6, which were assigned to (110), (111), (111), (200), (202), (002), (113), (220), and (311) planes, which are in good agreement with those of CuO-NPs obtained from international center of diffraction data (ICDD) card no (801916). This confirms the formation of crystalline monoclinic morphology. Copper oxide nanoparticles show sharp and well-defined reflections on XRD patterns which give the verification of the crystalline nature of $\mathrm{CuO}$ nanoparticles [29].

Furthermore, the crystallite size of CuO-NPs was $15 \mathrm{~nm}$, calculated by using the Debye Scherer equation $(D=k \lambda \beta \cos \theta)$, where $k, \lambda, \beta$, and $\theta$ are Scherer constant, wavelength of X-rays (1.5418 $\AA$ ), peak broadening at half the maximum intensity, and Bragg angle, respectively. Thus, the XRD analysis demonstrated that, initially, the particles are in the form of collides and then tend to grow and further react with environmental $\mathrm{O}_{2}$; this can be confirmed from SEM results that show some aggregates of particles; similar results were observed by Mojtaba Taran et al. [30].

3.2. Scanning Electron Mmicroscopy Analysis (SEM). SEM confirmed the morphology of the synthesized $\mathrm{CuO}$ nanoparticles. Figure 2 shows the morphological form of $\mathrm{CuO}$ NPs. From the SEM image, it is observed that the $\mathrm{CuO}$ nanoparticles are in highly collected form and have almost spherical morphology. The particle size of synthesized NPs was ranging from 14 to $100 \mathrm{~nm}$ with a mean particle size $50.1 \mathrm{~nm}$, measured by using ImageJ software. The results are consistent with XRD results.

3.3. Fourier Transform Infra Red Microscopy (FTIR). Figure 3 showed the FTIR spectrum of the copper oxide nanoparticles in the range of $400-4000 \mathrm{~cm}^{-1}$ at room temperature. The Infrared (IR) spectrum of $\mathrm{CuO}-\mathrm{NPs}$ shows the band at $3340.21 \mathrm{~cm}^{-1}, 1636.58 \mathrm{~cm}^{-1}, 1562.35 \mathrm{~cm}^{-1}$, $1412.25 \mathrm{~cm}^{-1}, 1021.14 \mathrm{~cm}^{-1}, 800.58 \mathrm{~cm}^{-1}, 600.14 \mathrm{~cm}^{-1}$, and $518.39 \mathrm{~cm}^{-1}$; characteristic peaks of copper oxides are positioned between 518.4 and $1021.1 \mathrm{~cm}^{-1}$. The peaks observed at $518.4 \mathrm{~cm}^{-1}$ and $600.1 \mathrm{~cm}^{-1}$ indicated the formation of 


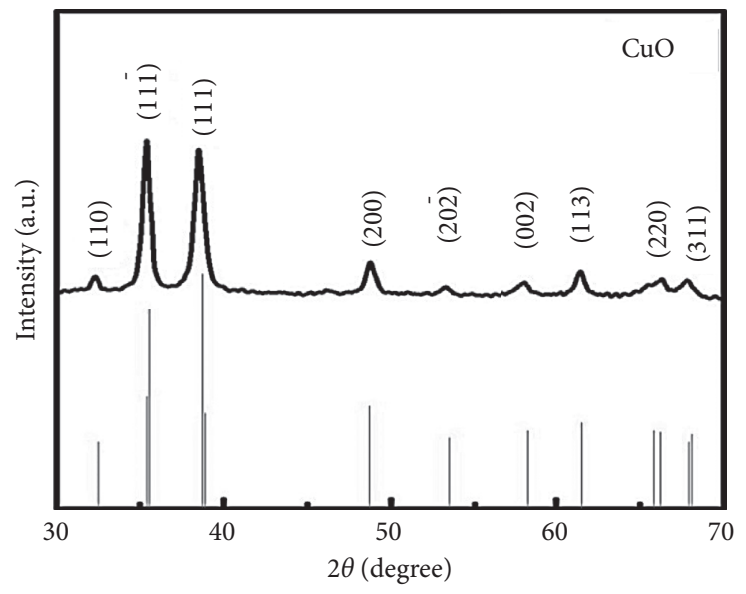

FIGURE 1: XRD patterns of copper oxide nanoparticles (CuO-NPs).

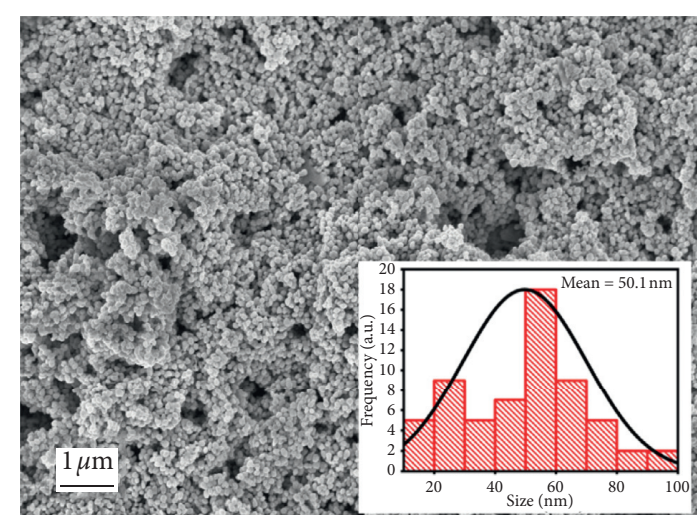

(a)

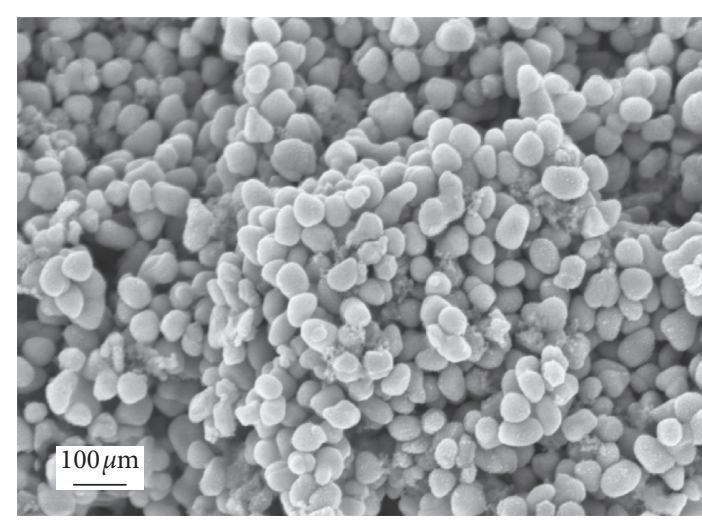

(b)

FIgURE 2: SEM micrograph of copper oxide nanoparticles.

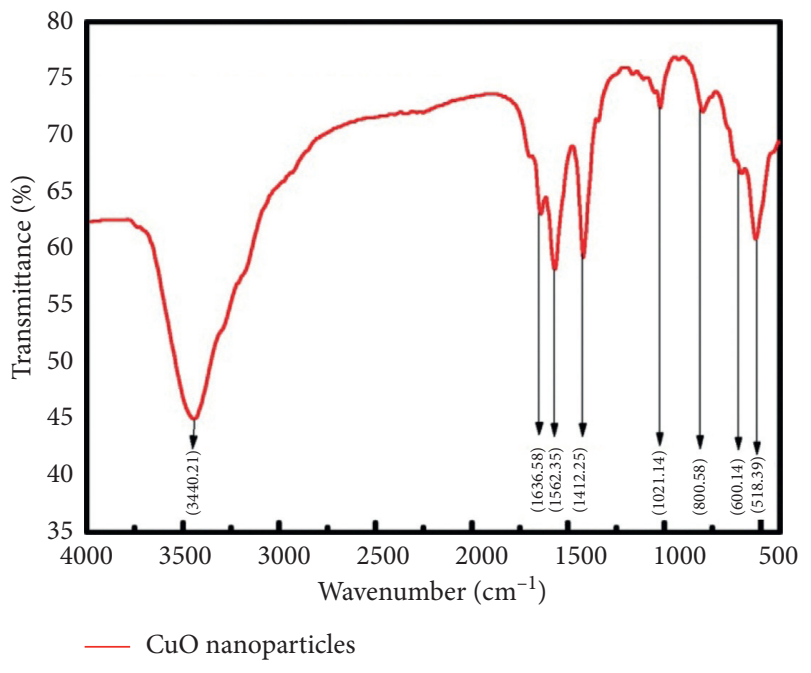

FIgURE 3: FTIR analysis of copper oxide nanoparticles.

$\mathrm{CuO}$ nanostructure and $\mathrm{Cu}-\mathrm{O}$ stretching. Peaks $1021.14 \mathrm{~cm}^{-1}$ and $800.58 \mathrm{~cm}^{-1}$ can be assigned to $\mathrm{C}-\mathrm{O}$ and $\mathrm{C}-\mathrm{H}$ bending. The peaks observed between 1412.3 and
$1636.4 \mathrm{~cm}^{-1}$ correspond to $\mathrm{O}-\mathrm{H}$ bending and $\mathrm{C}=\mathrm{C}$ stretching. The peak at 3440.2 is assigned to $\mathrm{N}-\mathrm{H}$ stretching which might be due to amino acid which also acts as capping agent [27].

\subsection{Antibacterial Activity of Copper Oxide Nanoparticles}

3.4.1. Antibacterial Activity at a Concentration of $50 \mu \mathrm{g} / \mathrm{mL}$. Antibacterial activities of CuO-NPs were checked in vitro against $P$. aeruginosa, Escherichia coli, Staphylococcus aureus, and $A$. baumannii at a concentration of $50 \mu \mathrm{g} / \mathrm{ml}$ (Figure 4; Table 1). DMSO was used as negative while for positive control, Norfloxacin was used. Norfloxacin is a broad-spectrum antibacterial agent. This study comprised of in vitro activity against a broad range of Gram-positive and Gram-negative bacterial strains; therefore, we selected this broad-spectrum drug as a positive control. It was investigated that $\mathrm{CuO}-\mathrm{NPs}$ were more effective against $S$. aureus, $P$. aeruginosa, $A$. baumannii, and $E$. coli, respectively. The sample showed a maximum inhibition zone of $9 \pm 1 \mathrm{~mm}$ against $S$. aureus while $A$. javanica extracts display a maximum zone of inhibition of $4 \pm 1 \mathrm{~mm}$ against $P$. aeruginosa. 


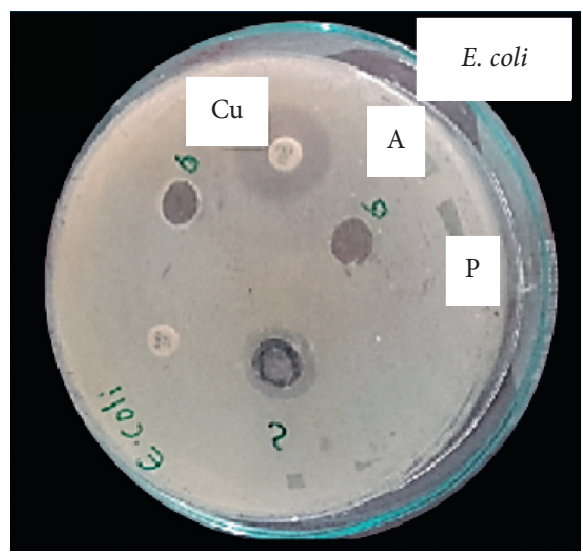

(a)

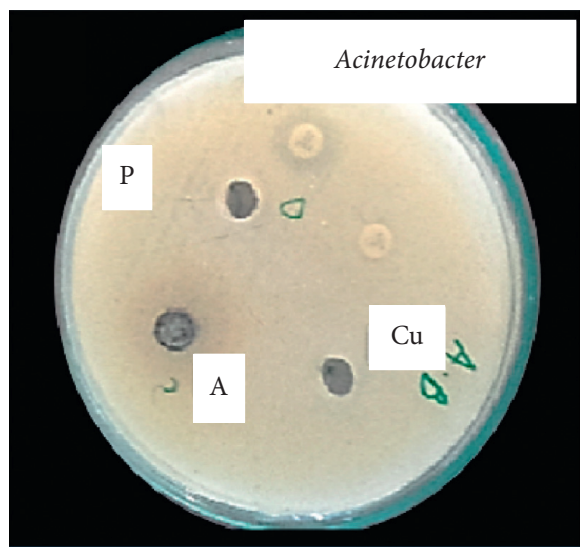

(c)

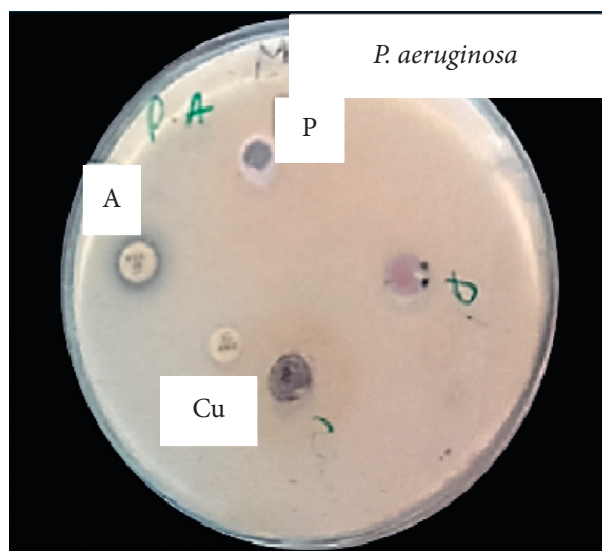

(b)

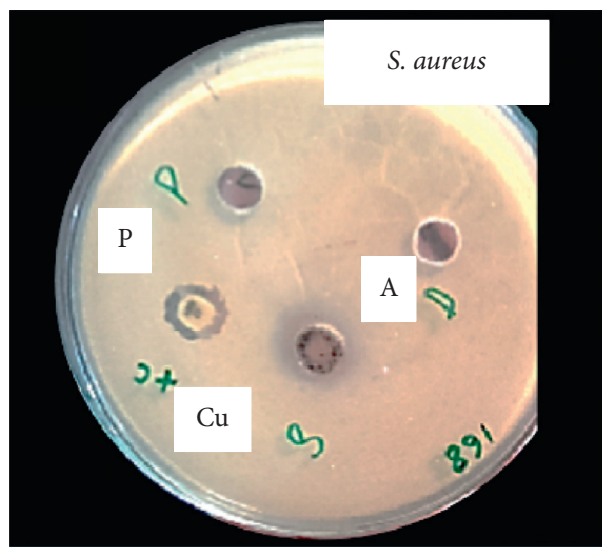

(d)

Figure 4: Antibacterial activity of CuO-NPs against all selected bacterial pathogens at a concentration of $50 \mathrm{ug} / \mathrm{ml}$ : (a) E. coli. (b) P. aeruginosa. (c) A. baumannii. (d) S. aureus.

TABLE 1: Different inhibition zone of CuO-NPs against selected bacterial strains.

\begin{tabular}{lcccc}
\hline- & & \multicolumn{2}{c}{ Inhibition of zone $(\mathrm{mm})$ against fungal strains } \\
- & E. coli & P. aeruginosa & S. aureus & Acinetobacter \\
\hline CuO-NPs & $5 \pm 1$ & $5 \pm 1$ & $9 \pm 1$ & $5 \pm 1$ \\
Aerva javanica leaf extract & $2 \pm 1$ & 0 & 0 & 0 \\
Norfloxacin & $12 \pm 0$ & $5 \pm 0$ & $4 \pm 0$ & $3 \pm 1$ \\
DMSO & 0 & 0 & 0 & 0 \\
\hline
\end{tabular}

Norfloxacin as a positive control; DMSO $=$ dimethyl sulfoxide as negative control; \pm standard error mean.

3.4.2. Antibacterial Activity at a Concentration of $100 \mu \mathrm{g} / \mathrm{mL}$. Antibacterial activities of $\mathrm{CuO}-\mathrm{NPs}$ were checked in vitro against $P$. aeruginosa, E. coli, $S$. aureus, and A. baumannii at a concentration of $100 \mu \mathrm{g} / \mathrm{ml}$ (Figure 5; Table 2). For negative control, DMSO was used and antibiotic Norfloxacin was used as a positive control. Average inhibition zones were calculated after three repeats. It was investigated that $\mathrm{CuO}-\mathrm{NPs}$ are more effective against $S$. aureus, Acinetobacter, $P$. aeruginosa, and E. coli, respectively. Sample shows a maximum inhibition zone of $12 \pm 1 \mathrm{~mm}$ against $S$. aureus while Aerva javanica extract showed maximum inhibition zone against all selected bacteria $(4 \pm 1 \mathrm{~mm})$.
3.4.3. Antibacterial Activity at a Concentration of $200 \mu \mathrm{g} / \mathrm{mL}$. Antibacterial activities of $\mathrm{CuO}-\mathrm{NPs}$ were checked in vitro against $P$. aeruginosa, E. coli, S. aureus, and A. baumannii at a concentration of $200 \mu \mathrm{g} / \mathrm{ml}$ (Figure 6; Table 3). Antibiotic Norfloxacin was used as a positive control; DMSO was used as a negative control. It was found that $\mathrm{CuO}-\mathrm{NPs}$ showed a maximum inhibition zone of $13 \pm 1 \mathrm{~mm}$ against $P$. aeruginosa and Acinetobacter.

3.5. Antifungal Activity of CuO-NPs. Antifungal activities of $\mathrm{CuO}-\mathrm{NPs}$ were checked in vitro against $C$. albicans, C. krusei, and C. tropicalis at a concentration of $100 \mu \mathrm{g} / \mathrm{mL}$ 


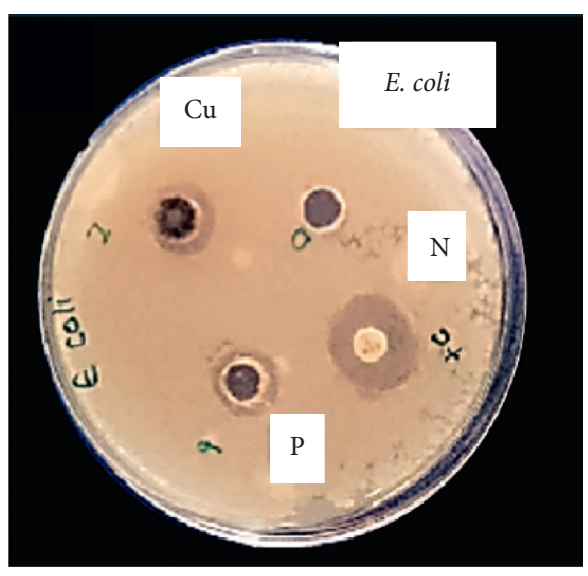

(a)

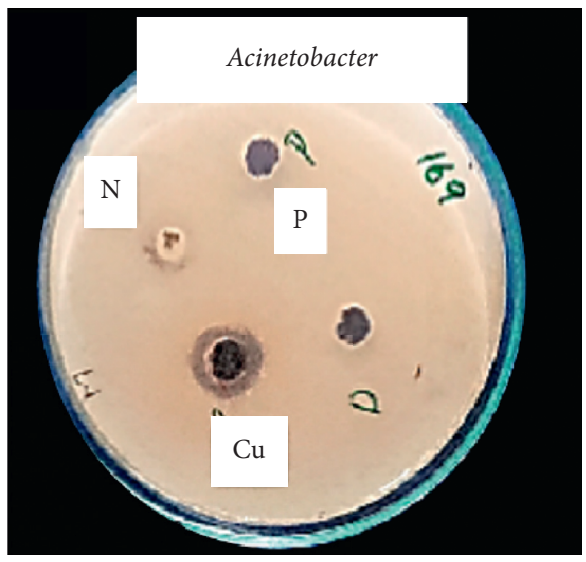

(c)

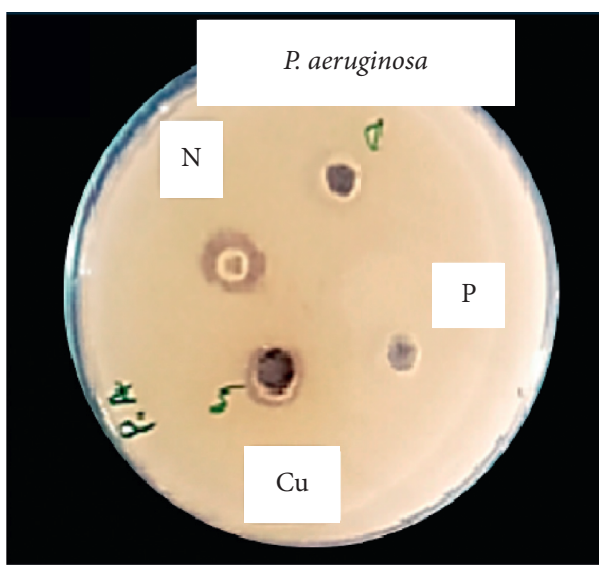

(b)

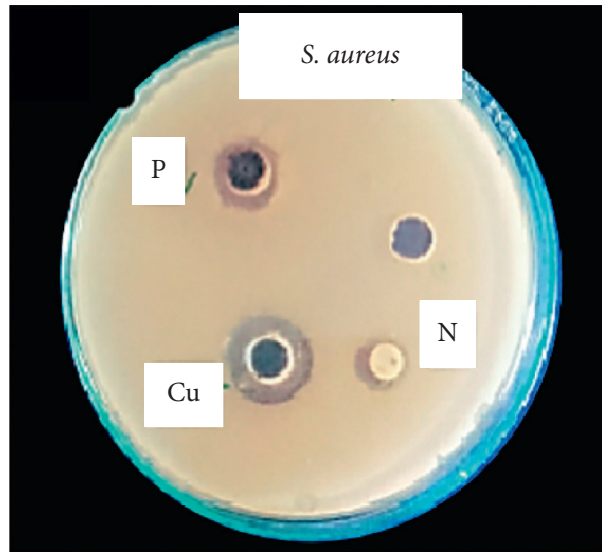

(d)

FIgURE 5: Antibacterial activity of copper oxide nanoparticle against selected bacterial strains at a concentration of $100 \mu \mathrm{g} / \mathrm{ml}$ : (a) E. coli. (b) P. aeruginosa. (c) Acinetobacter. (d) S. aureus.

TABLe 2: Different zone of inhibition of CuO-NPs against selected bacterial strains.

\begin{tabular}{lcccc}
\hline- & \multicolumn{3}{c}{ Inhibition zone $(\mathrm{mm})$ against fungal strains } \\
- & E. coli & P. aeruginosa & S. aureus & Acinetobacter \\
\hline CuO-NPs & $6 \pm 1$ & $10 \pm 1$ & $12 \pm 1$ & $12 \pm 1$ \\
A. Javanica leaf extract & $4 \pm 1$ & $3 \pm 1$ & $3 \pm 1$ & $2 \pm 0.25$ \\
Norfloxacin & $14 \pm 1$ & $5 \pm 0$ & $5 \pm 0$ & $5 \pm 1$ \\
DMSO & 0 & 0 & 0 & 0 \\
\hline
\end{tabular}

Norfloxacin as a positive control; DMSO = dimethyl sulfoxide as negative control; \pm standard error mean.

(Figure 7; Table 4). Amphotericin B antibiotic was used as a positive control and DMSO was used as a negative control. It was investigated that copper oxide nanoparticles showed a maximum zone of inhibition of $9 \pm 0.5 \mathrm{~mm}$ against C. albicans.

\subsection{Minimum Inhibitory Concentration (MIC) and Minimum Bactericidal Concentration (MBC)}

3.6.1. Minimum Inhibitory Concentration (MIC). When the MIC of copper oxide nanoparticles was examined, it was concluded that it showed the highest antibacterial activity. The MIC value for $\mathrm{CuO}-\mathrm{NPs}$ was at a concentration of
$128 \mu \mathrm{g} / \mathrm{mL}$ and $256 \mu \mathrm{g} / \mathrm{ml}$ which were examined against all selected bacterial pathogens. Results confirm that the MIC was effective at a concentration of $128 \mu \mathrm{g} / \mathrm{ml}$ (Table 5).

3.6.2. Minimum Bbactericidal Cconcentration (MBC). The copper oxide nanoparticles were effective bacteriostatic at a concentration of $128 \mu \mathrm{g} / \mathrm{mL}$ and $256 \mu \mathrm{g} / \mathrm{mL}$ against all the bacterial pathogens that are selected (Table 5).

3.6.3. Minimum Inhibitory Concentration (MIC) for Fungus. When the MIC of CuO-NPs was performed, it was noticed that it exhibited the highest antifungal activity. The 


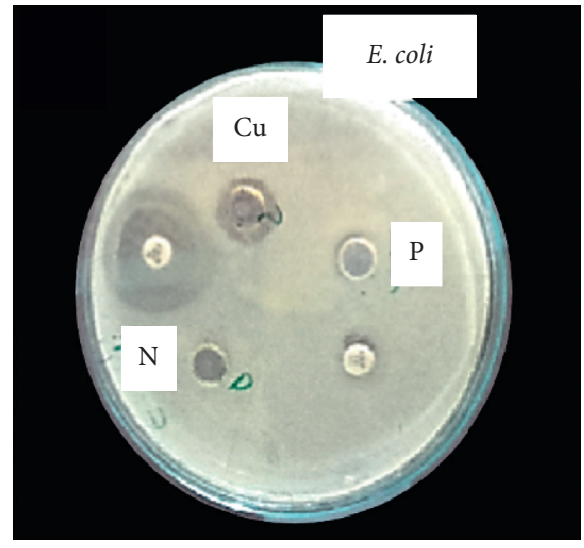

(a)

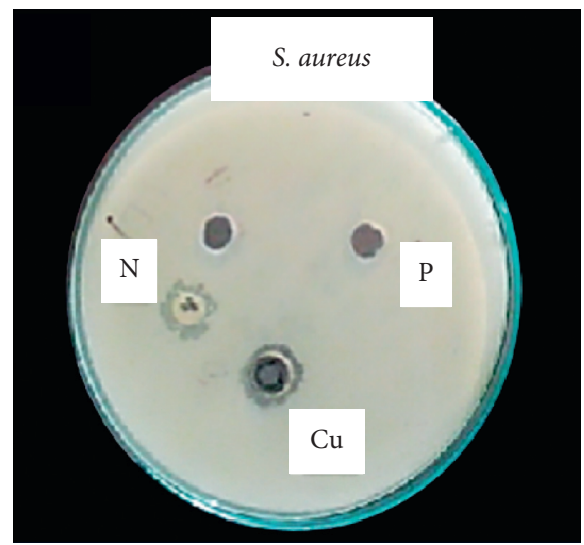

(c)

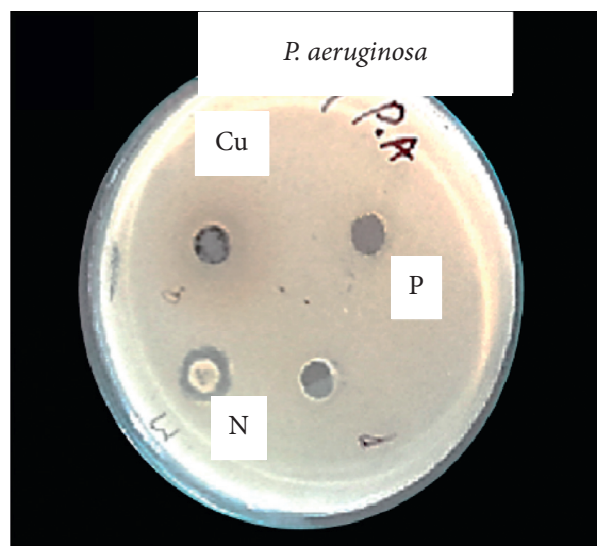

(b)

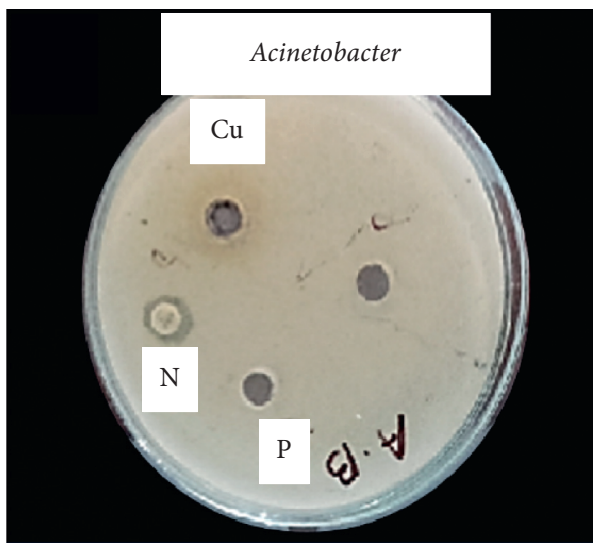

(d)

FIgURE 6: Antibacterial activity of CuO-NPs against selected bacterial strains at a concentration of $200 \mu \mathrm{g} / \mathrm{ml}$ : (a) E. coli. (b) P. aeruginosa. (c) S. aureus. (d) Acinetobacter.

TABLE 3: Different inhibition zones of all samples against selected bacterial strains.

\begin{tabular}{lcccc}
\hline- & & \multicolumn{2}{c}{ Inhibition zone $(\mathrm{mm})$ against fungal strains } \\
- & E. coli & P. aeruginosa & S. aureus & $12 \pm 1$ \\
CuO-NPs & $7 \pm 0.57$ & $13 \pm 1$ & $5 \pm 0.35$ & $12 \pm 1$ \\
Aerva javanica leaf extract & $5 \pm 0.35$ & $4 \pm 0$ & $5 \pm 1$ & $4 \pm 0$ \\
Norfloxacin & $15 \pm 1$ & $5 \pm 0$ & 0 & $6 \pm 0$ \\
DMSO & 0 & 0 & 0 \\
\hline
\end{tabular}

Norfloxacin as a positive control; DMSO = dimethyl sulfoxide as negative control; \pm standard error mean.

MIC value for $\mathrm{CuO}-\mathrm{NPs}$ was at a concentration of $160 \mu \mathrm{g} /$ $\mathrm{mL}$ and $320 \mu \mathrm{g} / \mathrm{mL}$, which were observed against all selected fungal pathogens. Results confirm that the MIC was found to be effective at a concentration of $160 \mu \mathrm{g} / \mathrm{ml}$ (Table 6).

3.6.4. Minimum Fungicidal Concentration (MFC). The copper oxide nanoparticle was found to be effective and fungistatic at a concentration of $160 \mu \mathrm{g} / \mathrm{mL}$ and $320 \mu \mathrm{g} / \mathrm{mL}$ against all selected bacteria. The result confirms the highest MFC of CuO-NPs was effective at a dilution of $160 \mu \mathrm{g} / \mathrm{ml}$ against all the fungal pathogens that are selected (Table 6).
3.7. Cytotoxicity Results. CuO-NPs show incredible antibacterial properties against Gram-negative and Grampositive bacteria. According to reported literature, in vitro various human cell lines like neuronal cells, cardiac microvascular endothelial cells, kidney cell, liver cell, and lung epithelial cells demonstrated that $\mathrm{CuO}$ nanoparticles cytotoxicity is mediated by oxidative stress. Thus, the excessive use of CuO-NPs and their disposal increases the risk of its potential toxicity to environmental and human health. Therefore, it necessary to determine the biocompatibility of synthesized CuO-NPs [31-34]. Hence, the cytotoxic properties of $\mathrm{CuO}-\mathrm{NPs}$ were performed on Neuro2A cells using MTT assays [28]. Different doses of $\mathrm{CuO}-\mathrm{NPs}$ from 0 to $600 \mu \mathrm{g} / \mathrm{ml}$ were used to complete this 


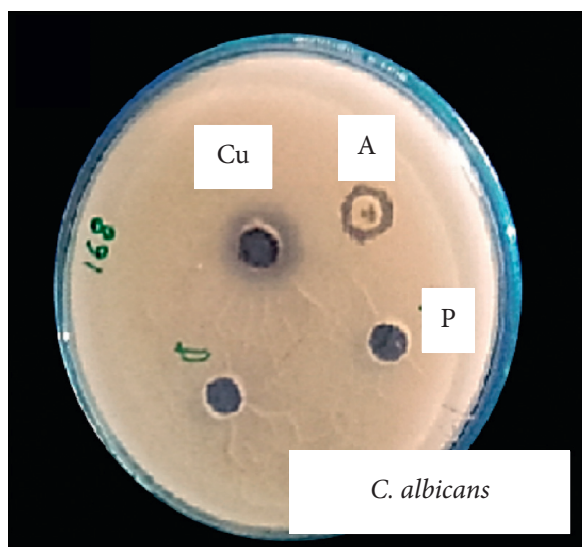

(a)

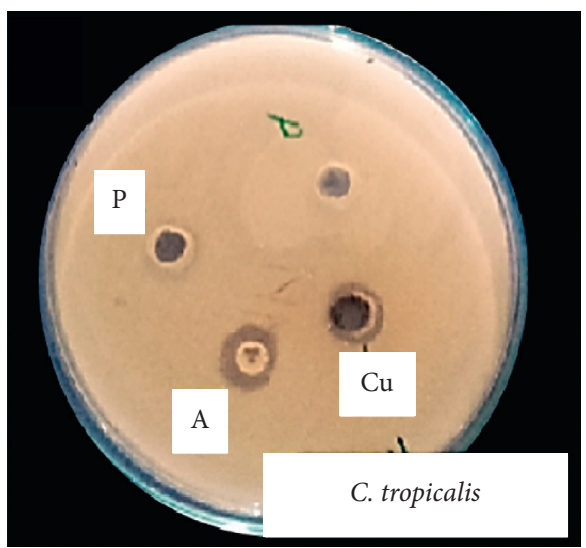

(c)

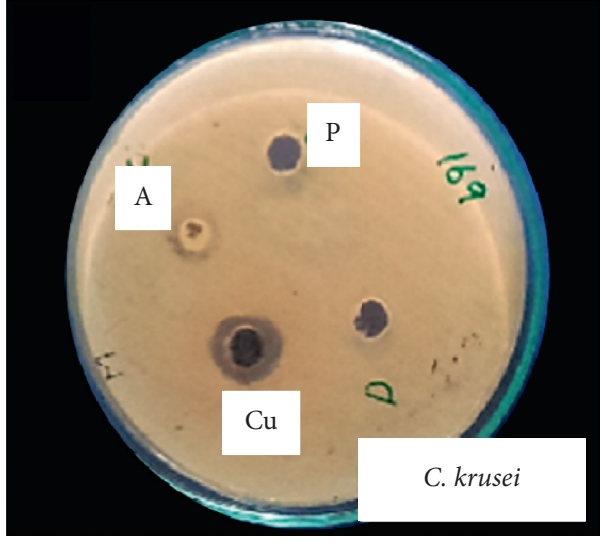

(b)

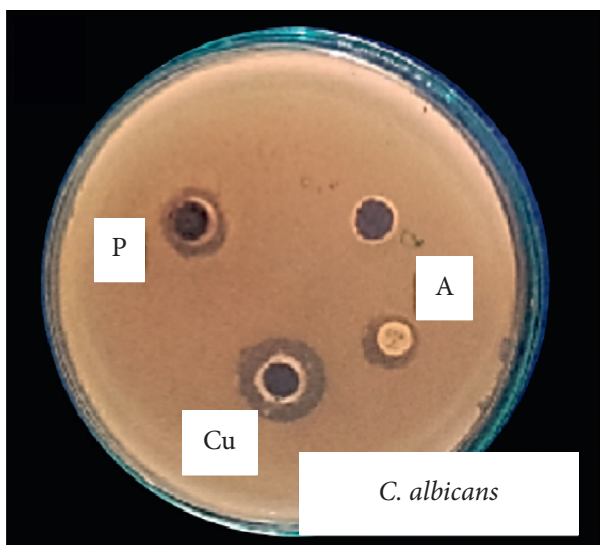

(d)

Fig-7: Antifungal activity of $\mathrm{CuO}-\mathrm{NPs}$ against selected fungus pathogens at a concentration of $100 \mu \mathrm{g} / \mathrm{ml}$ : (a) C. albicans. (b) C. krusei. (c) C. tropicalis. (d) C. albicans.

Table 4: Different inhibition zones of all samples fungal pathogens Candida albicans.

\begin{tabular}{lcccc}
\hline- & \multicolumn{3}{c}{ Inhibition zone $(\mathrm{mm})$ against fungal strains } \\
- & C. albicans & C. krusei & C. tropicalis & C. albicans \\
\hline CuO-NPs & $9+0.5$ & $5+1$ & $4+0$ & $7+1$ \\
Aerva javanica leaf extract & 0 & 0 & $3+0$ & $3+0.5$ \\
Amphotericin B & $4+1$ & $3+0$ & $3+1$ & $3+0$ \\
DMSO & 0 & 0 & 0 & 0 \\
\hline
\end{tabular}

TABLE 5: MIC and MBC determination of coppe oxide nanoparticles.

\begin{tabular}{|c|c|c|c|c|c|c|}
\hline \multirow{2}{*}{ Bacterial strains } & \multicolumn{6}{|c|}{ Concentrations } \\
\hline & $256 \mu \mathrm{g} / \mathrm{mL}$ & $128 \mu \mathrm{g} / \mathrm{mL}$ & $46 \mu \mathrm{g} / \mathrm{mL}$ & $32 \mu \mathrm{g} / \mathrm{mL}$ & $16 \mu \mathrm{g} / \mathrm{mL}$ & $8 \mu \mathrm{g} / \mathrm{mL}$ \\
\hline Escherichia coli & - & - & + & + & + & + \\
\hline Pseudomonas aeruginosa & - & - & - & + & + & + \\
\hline Staphylococcus aureus & - & - & + & + & + & + \\
\hline Acinetobacter baumannii & - & - & - & + & + & + \\
\hline
\end{tabular}

Positive $(+)=$ growth; negative $(-)=$ no growth .

examination (Table 7). Concentrations of synthesized nanoparticles below $15.62 \mu \mathrm{g} / \mathrm{mL}$ appeared to contain lower toxicity, as observed in the findings. From this, it can be deduced that CuO-NPs are harmless and industrially applicable with low risk at concentrations below $60 \mu \mathrm{g} / \mathrm{ml}[35]$. 
TABLE 6: MIC and MFC determination of copper oxide nanoparticles.

\begin{tabular}{lcccccc}
\hline \multirow{2}{*}{ Fungal strains } & \multicolumn{5}{c}{ Concentrations } \\
& $320 \mu \mathrm{g} / \mathrm{mL}$ & $160 \mu \mathrm{g} / \mathrm{mL}$ & $80 \mu \mathrm{g} / \mathrm{mL}$ & $40 \mu \mathrm{g} / \mathrm{mL}$ & $20 \mu \mathrm{g} / \mathrm{mL}$ & + \\
\hline C. albicans & - & - & - & + & + & + \\
C. krusei & - & - & + & + & + \\
C. tropicalis & - & - & + & + & + \\
C. albicans & - & & + & + & + \\
\hline
\end{tabular}

Positive $(+)=$ growth; negative $(-)=$ no growth.

TABle 7: MTT assay results of synthesized $\mathrm{CuO}-\mathrm{NPs}$ at $550^{\circ} \mathrm{C}$.

\begin{tabular}{lcc}
\hline S. no. & Concentration $\mu \mathrm{g} / \mathrm{mL}$ & Cell visibility $(\%)$ \\
\hline 1 & 0 & 100 \\
2 & 600 & 35 \\
3 & 300 & 37 \\
4 & 150 & 44 \\
5 & 125 & 45 \\
6 & 100 & 60 \\
7 & 70 & 60 \\
8 & 60 & 80 \\
9 & 50 & 80 \\
10 & 30 & 80 \\
11 & 10 & 80 \\
\hline
\end{tabular}

\section{Discussion}

The copper oxide nanoparticles have attracted many research interests because of their significance and importance as catalyst, ceramic resistor, superconducting material, and gas sensor, as well as their roles in the pharmaceutical field and the energy sector [36]. The present study investigated the use of A. Javanica leaf extract for copper oxide nanoparticles synthesis. The extract of A. Javanica acts as a capping agent and reducing agent in the $\mathrm{CuO}$ nanoparticles synthesis. X-ray diffraction analysis was performed to determine the crystal structure and phase of copper oxide nanoparticles. XRD results confirmed that the particle size was $15 \mathrm{~nm}$, which was in close agreement with previously published data $[37,38]$. Morphology of copper oxide nano particles confirmed by scanning electron microscopy, which showed that the particles are spherical and are in $18-23 \mathrm{~nm}$ range. FTIR spectroscopy was carried out to identify different functional groups and biomolecules present in copper oxide nanoparticles. The result showed different peaks that indicated the formation of $\mathrm{CuO}$ nanostructures, $\mathrm{Cu}-\mathrm{O}$ stretches, and the presence of $\mathrm{CO}_{2}$ in the air and hydrated $\mathrm{CuO}$. In this study, the antimicrobial activity of copper oxide nanoparticle was tested against the fungal pathogen and Gram-negative and Gram-positive bacteria. The bacterial isolates, S. aureus, $P$. aeruginosa, E. coli, and A. baumannii, and fungal isolates, Candia albicans, were used in the study. Higher antibacterial activities were investigated against Gramnegative bacteria as compared to Gram-positive bacteria. This might be due to the thinner cell wall of Gram-negative bacteria as compared to Gram-positive bacteria; thus, the thinner wall allows easy penetration of NPs, which then causes the cell lysis [39].
According to previously investigated data, higher activities were observed against Gram-negative bacteria [40]. At the concentration of $50 \mu \mathrm{g} / \mathrm{mL}$, copper oxide nano particles showed the highest activity against all the selected bacteria. $\mathrm{CuO}$ nanoparticles showed the highest activity against $S$. aureus, while $A$. baumannii, $P$. aeruginosa, and E. coli showed the lowest activity. Previously investigated studies showed that $S$. aureus is less susceptible to $\mathrm{CuO}$ nanoparticle compared to E. coli [41].

At a concentration of $100 \mu \mathrm{g} / \mathrm{mL}, \mathrm{CuO}-\mathrm{NPs}$ showed better activity against all the selected bacteria. Bacterial isolates $S$. aureus and A. baumannii showed the highest activity and $P$. aeruginosa and $E$. coli showed the lowest activity while previously published data showed that, at the concentration of $50 \mu \mathrm{g} / \mathrm{mL}, E$. coli showed the highest activity [42]. At concentration $200 \mu \mathrm{g} / \mathrm{mL}, \quad P$. aeruginosa and A. baumannii showed the highest activity, which is in good agreement with previously published data which showed that E. coli and $P$. aeruginosa showed maximum activity at $250 \mu \mathrm{g} / \mathrm{ml}$ [43]. Copper oxide nanoparticles also showed maximum antifungal activity. At a concentration of $100 \mu \mathrm{g} / \mathrm{ml}, \mathrm{CuO}$ nanoparticles $C$. albicans showed maximum activity. Previously published data confirm that CuO-NPs showed maximum activity against Candida albicans [27]. The MIC and MBC were calculated in different concentrations of copper oxide nanoparticles. Different concentrations of all samples were made. Different dilutions of $\mathrm{CuO}$ nanoparticles $8 \mu \mathrm{g} / \mathrm{mL}$, $16 \mu \mathrm{g} / \mathrm{mL}, 32 \mu \mathrm{g} / \mathrm{mL}, 64 \mu \mathrm{g} / \mathrm{mL}, 128 \mu \mathrm{g} / \mathrm{mL}$, and $256 \mu \mathrm{g} / \mathrm{mL}$ were made. At a concentration of $128 \mu \mathrm{g} / \mathrm{mL}$, samples inhibit the growth of all selected bacteria. So MIC and MBC for all selected bacteria were $128 \mu \mathrm{g} / \mathrm{mL}$ [27]. MIC and MFC were calculated for fungus in different concentrations ranging from $10 \mu \mathrm{g} / \mathrm{mL}$ to $320 \mu \mathrm{g} / \mathrm{mL}$. Results indicated that the MIC and MFC for all selected Candida species were at $160 \mu \mathrm{g} / \mathrm{Ml}$, which are in good agreement with previously published data [27]. Moreover, besides the concentration of synthesized nanoparticles, the antibacterial activity of nanoparticles greatly depends on their size and surface area [40, 44]. Azam et al. studied the effect of the size of CuO-NPs on their antibacterial activity and they demonstrated that the smaller nanoparticles $(20 \mathrm{~nm})$ have higher activity than larger size NPs. Further, the small size NPs provide greater surface area for the production of reactive $\mathrm{O}_{2}$ species such as hydrogen peroxide, superanion radicals, and hydroxyl radicals [42, 45].

\section{Conclusion}

It is concluded that the synthesis of copper oxide nanoparticles by a green approach using Aerva javanica extract is 
inexpensive, very easy to carry out in any laboratory, and also nontoxic. XRD analysis confirmed the crystalline structure of $\mathrm{CuO}$ nanoparticles and investigated the size in the range of $15 \mathrm{~nm}$. SEM confirmed the spherical shape and particle size in 18 to $23 \mathrm{~nm}$ which is in good agreement with previously providing data. The FTIR confirmed different function group and physical interaction of macromolecules with CuO-NPs. The $\mathrm{CuO}$ nanoparticles showed desirable antibacterial, antifungal, and cytotoxic activities. In line with the findings of the inquiry into the toxicity of synthesized nanoparticles, these nanoparticles tend to be at low risk in terms of their use in the industry as long as they are applied at concentrations below $60 \mu \mathrm{g} / \mathrm{mL}$. However, further in vivo studies will explore their potential in using these against microbial infectious diseases.

\section{Data Availability}

All the available data are included within the article.

\section{Conflicts of Interest}

The authors declare that there are no conflicts of interest.

\section{Acknowledgments}

The authors extend their appreciation to the Deanship of Scientific Research at Princess Nourah Bint Abdulrahman University, Riyadh, Saudi Arabia, for funding this work through the Fast-Track Research Funding Program.

\section{References}

[1] T. Tuutijärvi, J. Lu, M. Sillanpää, and G. Chen, "As (V) adsorption on maghemite nanoparticles," Journal of Hazardous Materials, vol. 166, no. 2-3, pp. 1415-1420, 2009.

[2] H. S. Nalwa, "Handbook of nanostructured materials and nanotechnology," Journal of Macromolecular Science-Physics, Applied Organometallic Chemistry, vol. 5, p. 3461, 2000.

[3] S. Siddiqui, R. H. Goddard, and G. K. Bielmyer-Fraser, "Comparative effects of dissolved copper and copper oxide nanoparticle exposure to the sea anemone, Exaiptasia pallida," Aquatic Toxicology, vol. 160, pp. 205-213, 2015.

[4] H. Barabadi, Z. Alizadeh, M. T. Rahimi et al., "Nanobiotechnology as an emerging approach to combat malaria: a systematic review," Nanomedicine: Nanotechnology, Biology and Medicine, vol. 18, pp. 221-233, 2019.

[5] D. Vaidehi, V. Bhuvaneshwari, D. Bharathi, and B. P. Sheetal, "Antibacterial and photocatalytic activity of copper oxide nanoparticles synthesized using Solanum lycopersicum leaf extract," Materials Research Express, vol. 5, no. 8, Article ID 085403, 2018.

[6] M. L. W. Knetsch and L. H. Koole, "New strategies in the development of antimicrobial coatings: the example of increasing usage of silver and silver nanoparticles," Polymers, vol. 3, no. 1, pp. 340-366, 2011.

[7] S. Nations, M. Long, M. Wages, J. D. Maul, C. W. Theodorakis, and G. P. Cobb, "Subchronic and chronic developmental effects of copper oxide $(\mathrm{CuO})$ nanoparticles on Xenopus laevis," Chemosphere, vol. 135, pp. 166-174, 2015.

[8] F. Perreault, S. P. Melegari, C. H. Da Costa, A. L. de Oliveira Franco Rossetto, and W. G. Matias,
"Genotoxic effects of copper oxide nanoparticles in neuro 2A cell cultures," Science of The Total Environment, vol. 441, pp. 117-124, 2012.

[9] S. K. Das, M. M. R. Khan, A. K. Guha, and N. Naskar, "Bioinspired fabrication of silver nanoparticles on nanostructured silica: characterization and application as a highly efficient hydrogenation catalyst," Green Chemistry, vol. 15, no. 9, pp. 2548-2557, 2013.

[10] S. Iravani, "Green synthesis of metal nanoparticles using plants," Green Chemistry, vol. 13, no. 10, pp. 2638-2650, 2011.

[11] Y. Li, J. Liang, Z. Tao, and J. Chen, "Copper oxide nanomaterials prepared by solution methods, some properties, and potential applications: a brief review," Research Bulletin, vol. 43, p. 2380, 2007.

[12] R. Sankar, P. Manikandan, V. Malarvizhi, T. Fathima, K. S. Shivashangari, and V. Ravikumar, "Green synthesis of colloidal copper oxide nanoparticles using Carica papaya and its application in photocatalytic dye degradation," Spectrochimica Acta Part A: Molecular and Biomolecular Spectroscopy, vol. 121, pp. 746-750, 2014.

[13] P.-R. Hsueh, "New Delhi metallo- $\beta$-lactamase-1 (NDM-1): an emerging threat among enterobacteriaceae," Journal of the Formosan Medical Association, vol. 109, no. 10, pp. 685-687, 2010.

[14] R. P. Rastogi and B. N. Mehrotra, "Compendium of Indian medicinal plants," Journal of Central Drug Research Institute, vol. 15, p. 19, 1994.

[15] E. A. Aboutabl, "Phytochemical profile and bioactivity validation of traditional use of Aerva lanata and Aerva javanica," Journal of Phytomedicine, vol. 7, pp. 131-132, 1997.

[16] P. Chawla, A. Chawla, N. Vasudeva, and S. K. Sharma, "A review of chemistry and biological activities of the genus Aerva- desert plant," Journal of Acta Poloniae Pharmaceutica, vol. 2, pp. 171-177, 2012.

[17] L. A. Baltina, O. B. Flekhter, L. R. Nigmatullina, E. I. Boreko, N. I. Nikolaeva, and O. V. Tolstikov, "Lupane triterpenes and derivatives with antiviral activity," Bioorganic \& Medicinal Chemistry Letters, vol. 13, no. 20, pp. 3549-3552, 2003.

[18] H. M. Ahmed, B. Y. Nour, Y. G. Mohammed, and H. S. Khalid, "Antiplasmodial activity of some medicinal plants used in Sudanese folk-medicine," Environmental Health Insights, vol. 4, pp. 1-6, 2010.

[19] K. Reddy and V. Reddy, "Antihyperglycaemic activity of ethanol extract of Aerva javanica leaves in alloxan-induced diabetic mice," Journal of Pharmacy Research, vol. 7, pp. 1259-1261, 2009.

[20] K. Usmanghani and Nazir, "Chemical constituents of Aerva javanica," Fitoterapia, vol. 3, pp. 75-77, 1982.

[21] H. M. Radwan, N. M. Nazif, and A. A. Hamdy, "The lipid and flavonoidal constituents of Aerva javanica," Journal of Pharmaceutical Sciences, vol. 2, pp. 167-178, 1999.

[22] N. A. M. Saleh, R. M. A. Mansour, and K. R. Markham, "An acylated isorhamnetin glycoside from Aerva javanica," Phytochemistry, vol. 29, no. 4, pp. 1344-1345, 1990.

[23] S. S. Emam, "Phytochemical studies on the herb Aerva javanica growing in Egypt," Bulletin of Faculty of Agriculture University of Cairo, vol. 3, pp. 488-514, 1999.

[24] D. Pawar, S. Shahista, S. Deshmukh, and K. Rohini, "Green synthesis of copper nanoparticles using Gloriosa superb leaf extract," International Journal of Pharmacy and Pharmaceutical Research, pp. 203-209, 2017. 
[25] I. Siavash, "Green synthesis of metal nanoparticles using plants," Journal of Green Chemistry, vol. 13, pp. 2638-2650, 2011.

[26] S. A. Khan, S. Shahid, M. Jameel, and A. Ahmad, "In vitro antibacterial, antifungal and GC-MS analysis of seeds of mustard Brown," International Journal of Pharmaceutical Chemistry, vol. 4, pp. 107-115, 2016.

[27] K. Ramesh, A. Vijay, and V. Suresh Kumar, "The MIC and $\mathrm{MBC}$ of silver nanoparticles against Enterococcus faecalis A facultative anaerobe," Journal of Nanomedicin and Nanotechnology, vol. 6, p. 3, 2015.

[28] F. Charbgoo, M. Ramezani, and M. Darroudi, "Bio-sensing applications of cerium oxide nanoparticles: advantages and disadvantages," Biosensors and Bioelectronics, vol. 96, pp. 33-43, 2017.

[29] S. Yallappa, J. Manjanna, M. A. Sindhe, N. D. Satyanarayan, S. N. Pramod, and K. Nagaraja, "Microwave assisted rapid synthesis and biological evaluation of stable copper nanoparticles using T. arjuna bark extract," Spectrochimica Acta Part A: Molecular and Biomolecular Spectroscopy, vol. 110, pp. 108-115, 2013.

[30] M. Taran, M. Rad, and M. Alavi, "Antibacterial activity of copper oxide $(\mathrm{CuO})$ nanoparticles biosynthesized by Bacillus sp. FU4: optimization of experiment design," Pharmaceutical Sciences, vol. 23, no. 3, pp. 198-206, 2017.

[31] B. Fahmy and S. A. Cormier, "Copper oxide nanoparticles induce oxidative stress and cytotoxicity in airway epithelial cells," Toxicology in Vitro, vol. 23, no. 7, pp. 1365-1371, 2009.

[32] M. Ahamed, M. A. Siddiqui, M. J. Akhtar, I. Ahmad, A. B. Pant, and H. A. Alhadlaq, "Genotoxic potential of copper oxide nanoparticles in human lung epithelial cells," Biochemical and Biophysical Research Communications, vol. 396, no. 2, pp. 578-583, 2010.

[33] J. Sun, S. Wang, D. Zhao, F. H. Hun, L. Weng, and H. Liu, "Cytotoxicity, permeability, and inflammation of metal oxide nanoparticles in human cardiac microvascular endothelial cells," Cell Biology and Toxicology, vol. 27, no. 5, pp. 333-342, 2011.

[34] J. Xu, Z. Li, P. Xu, L. Xiao, and Z. Yang, "Nanosized copper oxide induces apoptosis through oxidative stress in podocytes," Archives of Toxicology, vol. 87, no. 6, pp. 1067-1073, 2013.

[35] M. Darroudi, M. Sarani, R. Kazemi Oskuee, A. Khorsand Zak, and M. S. Amiri, "Nanoceria: gum mediated synthesis and in vitro viability assay," Ceramics International, vol. 40, no. 2, pp. 2863-2868, 2014.

[36] D. Das, B. C. Nath, P. Phukon, and S. K. Dolui, "Synthesis and evaluation of antioxidant and antibacterial behavior of $\mathrm{CuO}$ nanoparticles," Colloids and Surfaces B: Biointerfaces, vol. 101, pp. 430-433, 2013.

[37] G. Ren, D. Hu, E. W. C. Cheng, M. A. Vargas-Reus, P. Reip, and R. P. Allaker, "Characterisation of copper oxide nanoparticles for antimicrobial applications," International Journal of Antimicrobial Agents, vol. 33, no. 6, pp. 587-590, 2009.

[38] R. Dastjerdi and M. Montazer, "A review on the application of inorganic nano-structured materials in the modification of textiles: focus on anti-microbial properties," Colloids and Surfaces B: Biointerfaces, vol. 79, no. 1, pp. 5-18, 2010.

[39] A. Pugazhendhi, S. S. Kumar, M. Manikandan, and M. Saravanan, "Photocatalytic properties and antimicrobial efficacy of Fe doped $\mathrm{CuO}$ nanoparticles against the pathogenic bacteria and fungi," Microbial Pathogenesis, vol. 122, pp. 84-89, 2018.
[40] R. Sankar, A. Karthik, A. Prabu, S. Karthik, K. S. Shivashangari, and V. Ravikumar, "Origanum vulgare mediated biosynthesis of silver nanoparticles for its antibacterial and anticancer activity," Colloids and Surfaces B: Biointerfaces, vol. 108, pp. 80-84, 2013.

[41] S. Sivaraj and R. Venckatesh, "Aloe barbadensis Miller mediated green synthesis of mono-disperse copper oxide nanoparticles: optical properties," Spectrocemica Acta A: Molecular and Biomolecular Spectroscopy, vol. 97, pp. 11401144, 2012.

[42] A. Maqusood, A. Hisham, and M. A. Alhadlaq, "Synthesis, characterization, and antimicrobial activity of copper oxide nanoparticles," Journal of Nanomaterials, vol. 2014, Article ID 637858, 4 pages, 2014.

[43] M. Heinlaan, A. Ivask, I. Blinova, H.-C. Dubourguier, and A. Kahru, "Toxicity of nanosized and bulk $\mathrm{ZnO}, \mathrm{CuO}$, and $\mathrm{TiO}_{2}$ to bacteria Vibrio fischeri and crustaceans Daphnia magna and Thamnocephalus platyurus," Chemosphere, vol. 71, no. 7, pp. 1308-1316, 2008.

[44] H. Vahidi, H. Barabadi, and M. Saravanan, "Emerging selenium nanoparticles to combat cancer: a systematic review," Journal of Cluster Science, vol. 31, no. 2, pp. 301-309, 2020.

[45] M. Taran, M. Rad, and M. Alavi, "Biological synthesis of copper nanoparticles by using Halomonas elongata IBRC-M 10214," Industria Textila, vol. 67, no. 5, pp. 351-356, 2016. 